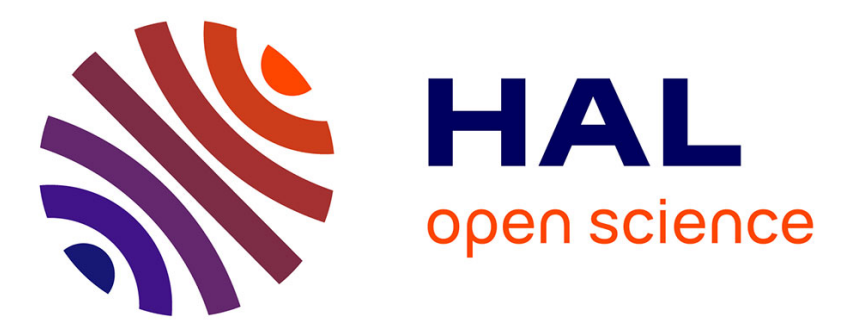

\title{
Effects of low and high temperature plasma nitriding on electrochemical corrosion of steel
}

\author{
K. Ram Mohan Rao, Corinne Nouveau, S. Lakshman, P. Muralidhar, K.
}

Trinadh

\section{- To cite this version:}

K. Ram Mohan Rao, Corinne Nouveau, S. Lakshman, P. Muralidhar, K. Trinadh. Effects of low and high temperature plasma nitriding on electrochemical corrosion of steel. Materials Today: Proceedings, 2020, 39, pp.1367-1371. 10.1016/j.matpr.2020.04.692 . hal-03222889

\section{HAL Id: hal-03222889 \\ https://hal.science/hal-03222889}

Submitted on 10 May 2021

HAL is a multi-disciplinary open access archive for the deposit and dissemination of scientific research documents, whether they are published or not. The documents may come from teaching and research institutions in France or abroad, or from public or private research centers.
L'archive ouverte pluridisciplinaire HAL, est destinée au dépôt et à la diffusion de documents scientifiques de niveau recherche, publiés ou non, émanant des établissements d'enseignement et de recherche français ou étrangers, des laboratoires publics ou privés. 


\title{
Effects of low and high temperature plasma nitriding on electrochemical corrosion of steel
}

\author{
K. Ram Mohan Rao ${ }^{\mathrm{a}, *}$, Corinne Nouveau ${ }^{\mathrm{b}}$, S. Lakshman ${ }^{\mathrm{a}}$, P. Muralidhar ${ }^{\mathrm{a}}$, K. Trinadh ${ }^{\mathrm{a}}$ \\ a Department of Chemistry, GITAM Institute of Science, Gandhi Institute of Technology \& Management, Rushikonda, Visakhapatnam 530045, Andhra Pradesh, India \\ ${ }^{\mathrm{b}}$ Laboratoire Bourguignon des Matériaux et Procédés (LaboMaP), Arts et Métiers Paris Tech de Cluny, Rue Porte de Paris, F-71250 Cluny, France
}

Keywords:

Corrosion

Polarization

Plasma nitriding

Tool steel

XRD

\begin{abstract}
A B S T R A C T
This study concerns plasma nitriding of tool steel at different temperatures and its effects on corrosion resistance. Inside the nitriding reactor steel samples were placed on the sample holder after metallographic polishing and then the vacuum chamber was evacuated to a pressure of $\sim 0.5 \mathrm{~Pa}$. At a lower temperature of $450{ }^{\circ} \mathrm{C}$ and the higher temperature of $550{ }^{\circ} \mathrm{C}$ nitriding was performed for a fixed duration of $10 \mathrm{~h}$.

All the nitrided and the bare steel samples studied under X-ray diffraction (XRD) and scanning electron microscopic analysis/energy dispersive X-ray spectroscopy (EDS). Iron nitride $\left(\mathrm{Fe}_{\mathrm{x}} \mathrm{N}, \mathrm{x}=2-3,4\right)$ peaks were revealed in the nitrided steels after XRD analyses. EDS revealed the increased amount of nitrogen in the nitrided sample treated at $550{ }^{\circ} \mathrm{C}$. For the assessment of corrosion resistance of these steel samples potentiodynamic polarization tests were performed in $3.5 \% \mathrm{NaCl}$. On comparison, it was found that the steel nitrided at higher temperature is more effective in enhancing the corrosion resistance.
\end{abstract}

\section{Introduction}

Surface modification of materials already been proved to improve the hardness, wear and corrosion resistance properties, which can prolong the service life of the components/tools. Generally, the layers with desirable hardness, wear and corrosion resistance have been deposited on the surface of the materials. For the same purpose, the surface can also be alloyed with the suitable elements. Physical and chemical vapour deposition are the most popular methods for the deposition however, the deposition may not be adherent enough to sustain in the working environment and thus limits the applications $[1,2]$.

Plasma mediated surface modification had been realized to be the right choice for prolonging the service life of components by overcoming problems with the deposited layer. Plasma nitriding is one of most promising surface modification methods, which has gained popularity than others. The modified surface does not face any interfacial adhesion problem as found at the interface of the layer deposited by PVD/CVD methods [3,4]. Efficiency, eco-

\footnotetext{
* Corresponding author.

E-mail address: rammohanrao.k@gmail.com (K. Ram Mohan Rao).
}

friendliness, process controllability and cost effectiveness have made plasma nitriding an attractive and popular method for the surface modification of materials like steel, titanium, ceramics for the improvement of properties e.g. mechanical, corrosion, biocompatibility etc. [5-15]. Nitriding eliminates the risk of delamination as found in the case of layer deposited by PVD/CVD. By controlling the process parameters e.g. pressure, temperature, time, current density etc., it is possible to achieve the desired properties. The much-improved results already been shown by the nitrided parts which the process became very much attractive particularly for the industrial sectors like tool and automobile industries etc.

Plasma nitriding involves the heating of the substrate kept on the sample holder in the nitriding reactor and biased negatively. Plasma nitriding system had already shown in the literature elsewhere [16-18]. The samples after metallographic polishing are placed inside the nitriding reactor on the sample holder. The vaccum chamber of the reactor then evacuated to $\sim 0.5 \mathrm{~Pa}$. Sample holder is connected to the dc power source, which maintains the negative biasing to certain voltage. Following this, the Ar + plasma is generated, then the positively charged $\mathrm{Ar}$ ions are attracted towards the sample surface. These ions sputter clean the dirt and native oxide deposited on the surface. The ion bombardment con- 
tinued until the temperature attains the desired degree of temperature. Once, the temperature attained, nitrogen and hydrogen gas mixture at certain ratio is fed into the chamber to a working pressure (in this study around $\sim 500 \mathrm{~Pa}$ ). Then the plasma of the gas mixture was triggred. The negatively biased sample attracts the ions of nitrogen and hydrogen from the plasma. These ions then adsorb on the sample surface. Subsequently on application of suitable temperature, nitrogen diffuses into the bulk of the substrate forming the desired phases and nitride layer.

So far very less is known about the plasma nitriding of chromium-molybdenum-vanadium tool steel. Corinne et al. [5] and extended by Rao et al. [6,7] had been working on this steel for the enhancement of hardness and corrosion resistance properties. As reported by Rao et al. [6] the hardness of steel significantly improves at the low temperature plasma nitriding. However, very less is known about the effect of plasma nitriding on corrosion resistance of this steel. The effect of high temperature plasma nitriding on corrosion resistance of this steel is also not yet attempted. The present work concerns the effect of plasma nitriding at the two extreme temperatures of 450 and $500{ }^{\circ} \mathrm{C}$. The focus of the present work is the effect of plasma nitriding on corrosion resistance in $3.5 \% \mathrm{NaCl}$ environment.

\section{Experimental}

Steel samples of dimension $10 \times 10 \times 6 \mathrm{~mm}^{3}$ were cut from a sheet after hardening and tempering heat treatment. The composition of steel is given as: $\mathrm{C}(0.5 \%), \mathrm{Si}(1.0 \%), \mathrm{Mn}(0.5 \%), \mathrm{Cr}(0.8 \%)$, Mo (1.5\%), V (0.5\%) and $\mathrm{Fe}(88 \%)$. The steel sample after metallographic polishing and cleaning ultrasonically was placed on the sample holder in the vacuum chamber of the nitriding reactor then evacuated the chamber to $0.5 \mathrm{~Pa}$ and biased negatively at $-250 \mathrm{~V}$. Then vacuum pressure was raised to $\sim 500 \mathrm{~Pa}$ by feeding the working gas. Initially, Ar gas was fed into the chamber and then triggered the $\mathrm{Ar}+$ plasma. Once the temperature attained to the desired level, a gas mixture of nirogen and hydrogen at a ratio of 80:20 fed into the chamber and triggered the plasma. Hydrogen gas was mixed with the nitrogen at 80:20 ratio in the plasma nitriding. Hydrogen plays the role to sputter clean the surface of the substrate and also for the chemical etching of the oxygen during nitriding. It has also been found that the hydrogen increases the chemical potential and the density of reactive nitrogen in the plasma [19-22]. The hydrogen in the range of $20-40$ percent in a gas mixture of nitrogen and hydrogen increases the efficiency of nitriding. Higher content of hydrogen above 40 percent the nitriding decelerates the nitriding process. This is because the amount of nitrogen and $\mathrm{N}-\mathrm{H}$ radicals in the plasma fall with increase in hydrogen content. The nitrided layer thickness and microhardness values reaches to maximum when the hydrogen content lies between 20 and 40 percent [23]. Hence, in the present study, the gas mixture was taken as $20 \%$ hydrogen and $80 \%$ nitrogen.

The positively charged nitrogen and hydrogen ions from the plasma accelerated towards the sample, which then adsorbed onto its surface. Subsequently, on heating nitrogen ions diffuse towards the bulk of the sample. Samples were heated to 450 and $550{ }^{\circ} \mathrm{C}$ for a fixed duration of $10 \mathrm{~h}$. Nitriding at these temperatures had been selected because of the faster diffusion kinetics of nitrogen in the steel within this temperature range. In addition to that the present study focussed on the effects of nitriding at low and high temperatures hence the two extreme temperatures of 450 and $550{ }^{\circ} \mathrm{C}$
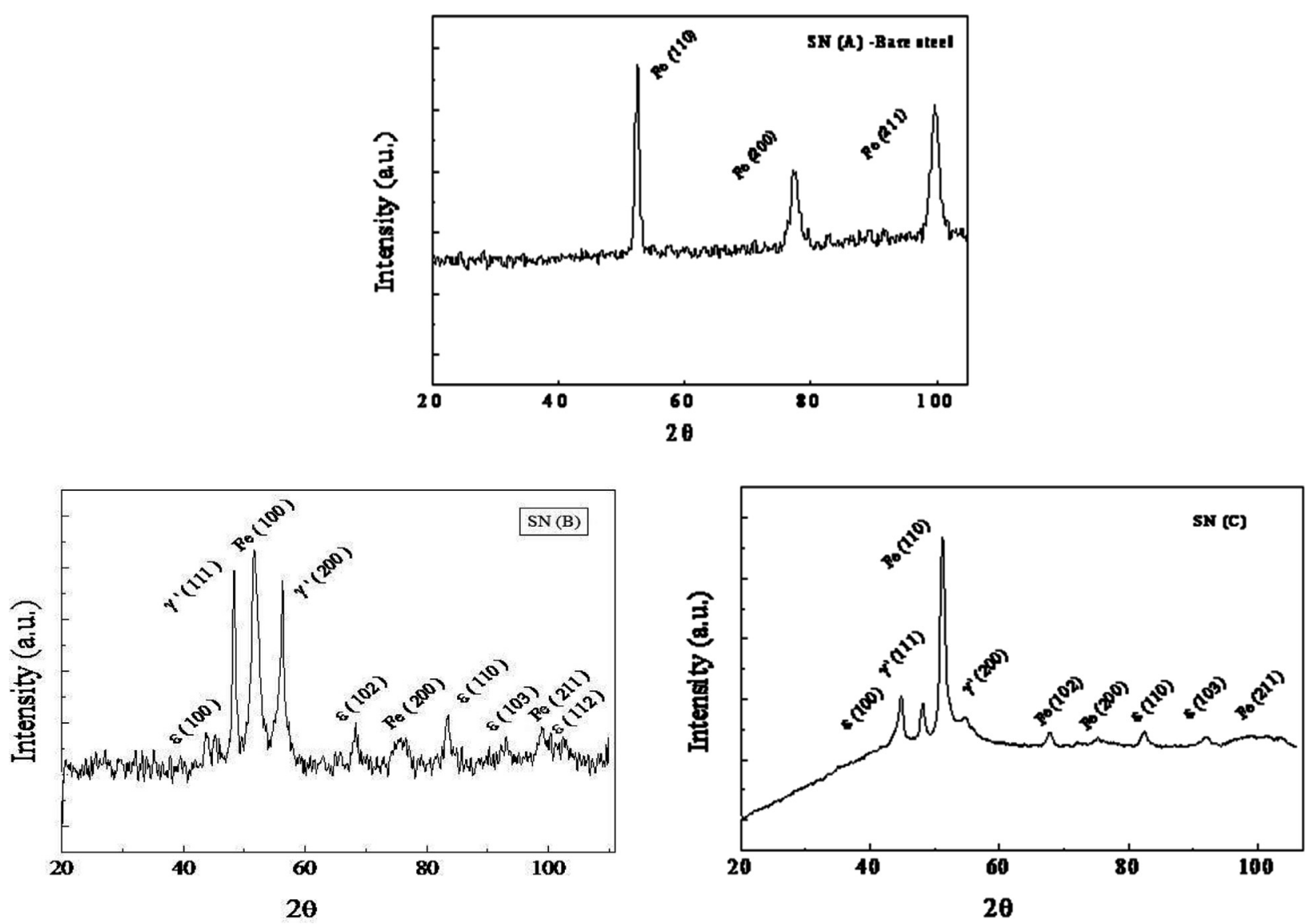

Fig. 1. XRD patterns of (a) bare steel; and after plasma nitriding at (b) $550{ }^{\circ} \mathrm{C}$ and (c) $450{ }^{\circ} \mathrm{C}$. 
were considered. Temperature below $450{ }^{\circ} \mathrm{C}$ may not be so effective for nitridring as the nitrogen diffusion co-efficient is higher in the range between $450{ }^{\circ} \mathrm{C}$ and $550^{\circ} \mathrm{C}$. Moreover, nitriding above $550{ }^{\circ} \mathrm{C}$ will reduce the core hardness significantly; hence the nitriding temperature had not been selected above this temperature.

To understand the phase formation or modification of surface microstructure of nitrided and the bare steel; these samples had been subjected to detailed XRD analyses. X-ray diffraction (XRD) studies had been carried out by using the diffractometer with Bragg -Brentano configuration and the Co- $k a$ radiation source $(0.17902 \mathrm{~nm})$.

Following the EDS microanalyses the elements were detected particularly to know about the relative concentrations of nitrogen in the nitrided steels at two different treatment temperatures.

Finally, the electrochemical characterization of bare and nitrided steels were performed by using the equipment Model SI 1287 Electrochemical Interface-Solatron Analytical, U.K. The tests were performed at room temperature in $3.5 \% \mathrm{NaCl}$. Samples were exposed to the electrolyte until the stable potential was attained. Then the potentiodyamic polarization tests in $3.5 \% \mathrm{NaCl}$ were performed.

\section{Results and discussions}

\subsection{Phase evolution and microstructure}

X-Ray diffraction studies: To understand about the phase formation after plasma nitriding the nitrided and bare steel samples were exposed to detailed XRD (with Co- $k \alpha$ radiation source). XRD patterns are revealed in Fig. 1 for the bare steel (SN (A)) and the steels after nitriding $550^{\circ} \mathrm{C}$ for $10 \mathrm{~h}(\mathrm{SN}(\mathrm{B}))$ and at $450{ }^{\circ} \mathrm{C}(\mathrm{SN}(\mathrm{C}))$.

The bare steel revealed mainly the iron peaks but the nitrided steels show iron peaks along with its nitrides $\left(\gamma^{\prime}-\mathrm{Fe}_{4} \mathrm{~N}, \varepsilon-\mathrm{Fe}_{2-3} \mathrm{~N}\right)$. When carefully observed, the Fe $\left(\begin{array}{lll}1 & 1 & 0\end{array}\right)$ peak is found to be shifted towards the left from its initial position. Initially, it was at the position of $52.77^{\circ}$ but after nitriding shifted to lower angle of $51.22^{\circ}$ which is caused by the nitrogen incorporation and hence the dilation of crystal lattice due to the compressive stress generation. Stress generation attributes to the improvement of hardness and fatigue properties. The shifting of the peak due to super saturation of nitrogen generates the phase, known as expanded martensite like expanded austenite when austenite phase is supersaturated by nitrogen. On the other hand, iron nitrides $\gamma^{\prime}-\mathrm{Fe}_{4} \mathrm{~N}$ and $\varepsilon-\mathrm{Fe}_{2}$ ${ }_{3} \mathrm{~N}$ also contribute to the hardness and corrosion resistance of the
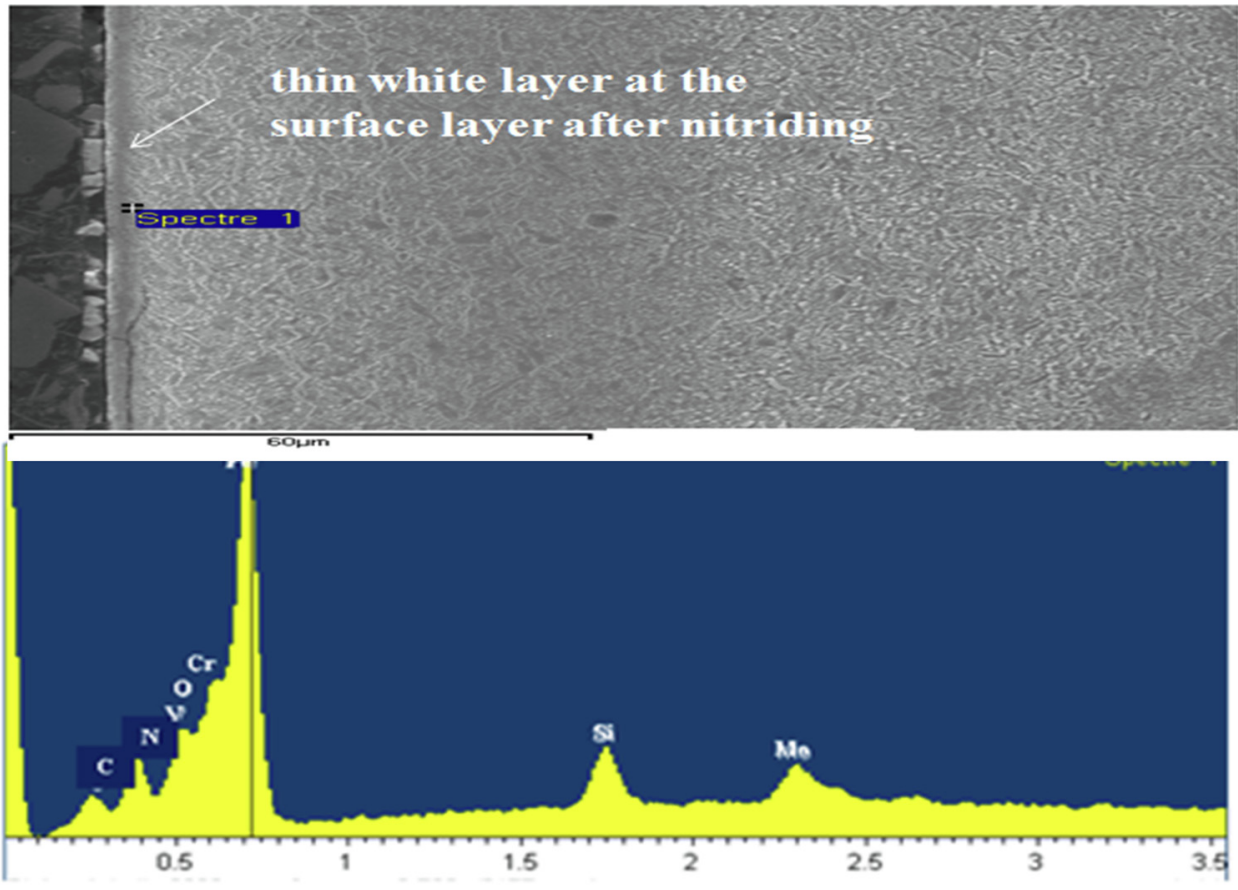

keV

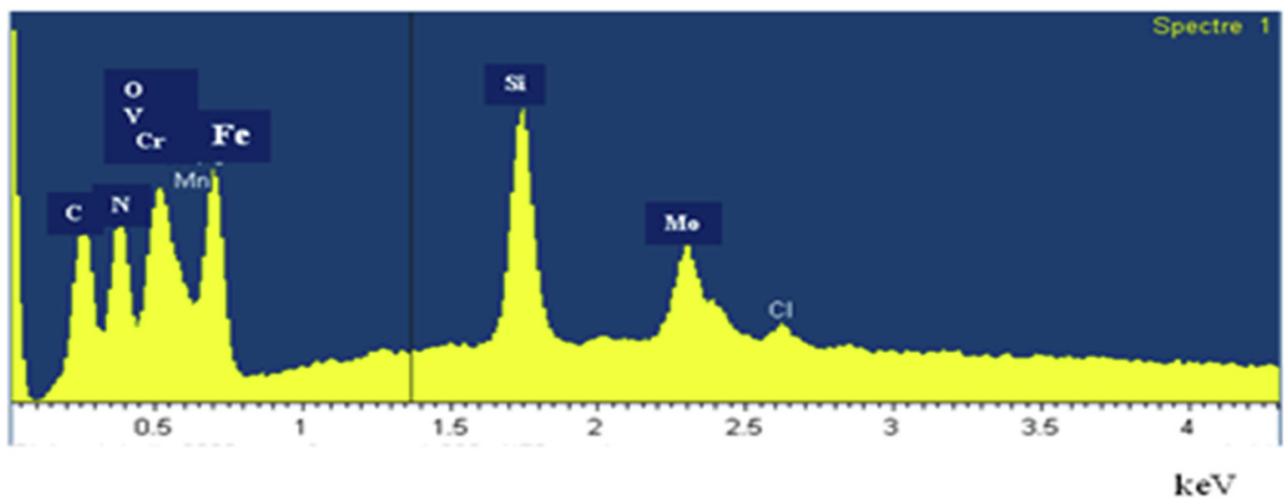

Fig. 2. (a) SEM for Cross-sectio of steel nitrided at $450^{\circ} \mathrm{C}$ for $10 \mathrm{~h}$; and EDS for nitrogen after nitriding at; (b) $450{ }^{\circ} \mathrm{C}$; (c) $550{ }^{\circ} \mathrm{C}$ for $10 \mathrm{~h}$. 


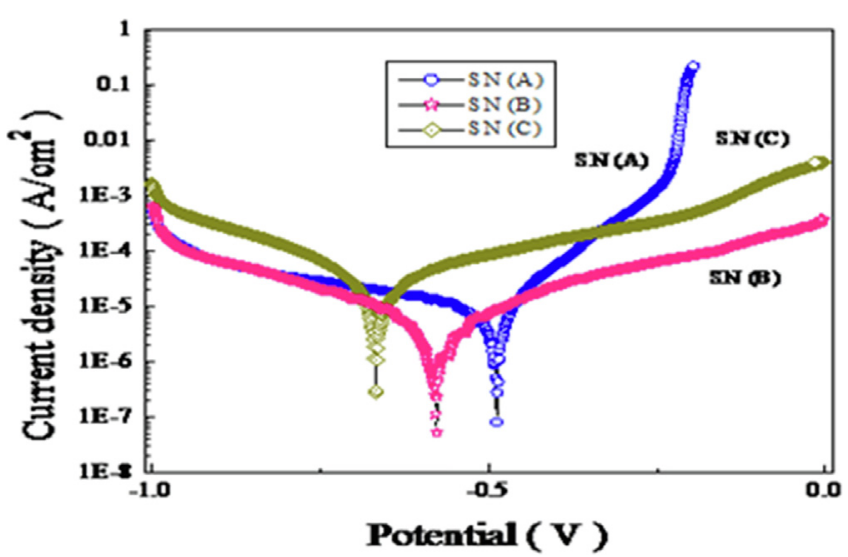

Fig. 3. Potentiodynamic polarization curves after test in $3.5 \% \mathrm{NaCl} \rightarrow \mathrm{SN}$ (A) (bare); nitrided steel (b) $\mathrm{SN}(\mathrm{B})\left(550^{\circ} \mathrm{C}\right)$ and; $\mathrm{SN}(\mathrm{C})\left(450^{\circ} \mathrm{C}\right)$.

steel. The nitrogen solubility seems to be more in the crystal lattice when the nitriding temperature raised to $550^{\circ} \mathrm{C}$ for the same duration of $10 \mathrm{~h}$.

Scanning electron microscopic studies: To understand the effects of nitriding on the microstructure of the nitrided steel, a sample nitrided at $450^{\circ} \mathrm{C}$ for $10 \mathrm{~h}$ as representative sample was selected (Fig. 2). First the sample was cross sectioned and mirror polished and then etched with the Villela's reagent. Following this the sample was exposed to SEM. The cross sectional microstructure shows a very thin white layer which is a good indication of mechanical integrity. It is expected; that the thinner the white layer better will be the wear resistance. The nitrided layer/diffusion layer follows the thin layer. The EDS analyses reveal that the concentration of nitrogen in the steel after nitriding at $550{ }^{\circ} \mathrm{C}$ for $10 \mathrm{~h}$ is more than that of the steel nitrided at $450^{\circ} \mathrm{C}$ for the same duration, which is evidenced by Fig. 2 (b and c). This means that the nitrogen diffusion is more when the nitriding temperature raised to the higher temperature of $550{ }^{\circ} \mathrm{C}$ when compared to the nitrogen diffusion in the steel nitrided at the temperature of $450{ }^{\circ} \mathrm{C}$. The higher content of nitrogen may affect the nitride concentration and/or the nitrogen supersaturation in the crystal lattice. This will have an effect on hardness and the corrosion resistance. It is expected that the improvement in hardness and corrosion resistance is caused by the presence of iron nitrides and nitrogen super saturation. As the focus of this study is plasma nitriding for the improvement of corrosion resistance property, the following section is concentrated on the assessment of corrosion resistance of nitrided steels.

\subsection{Electrochemical characterization}

Potentiodynamic polarization tests: For the assessment of corrosion resistance of bare and nitrided steels potentiodynamic polarization tests were followed. All the tests were performed at room temperature in $3.5 \% \mathrm{NaCl}$ electrolyte. Initially, samples exposed to the electrolyte had shown the fluctuation of the potential. It was immersed in the electrolyte for nearly $1 \mathrm{~h}$ until the stability was gained by the samples. Then potentiodynamic polarization initiated. Fig. 3 shows the polarization diagrams of bare and nitrided steels. It is obvious from these polarization curves that the bare steel is nobler to corrosion initially but after lapse of time the rate of corrosion found to be faster than the nitrided steel SN (B). From the Tafel extrapolation calculations it was found that the nitrided steel SN (B) has shown $\mathrm{E}_{\text {corr }}$ value $-0.57483(\mathrm{~V})$ which predicts the corrosion propensity is relatively less than the nitrided steel $\mathrm{SN}(\mathrm{C})$ which has $\mathrm{E}_{\mathrm{corr}}$ value $-0.66333(\mathrm{~V})$. In any case, the nitrided steels show more negative potential than the bare steel indicating the propensities more towards the corrosion. This means the surface reactivity might have increased after nitriding. The more reactivity might have caused by the presence of nitrides and hence the heterogeneity developed on the surface of the nitrided steels.

The passivation shown by the SN (C) is wider than the bare steel. However, the steel SN (B) at the much lower current density had shown the wider passive region. These observations leads to the conclusion that the nitriding at higher temperature $550{ }^{\circ} \mathrm{C}$ for $10 \mathrm{~h}$ is much better than the steel nitrided at the lower temperature of $450{ }^{\circ} \mathrm{C}$ for the same duration. From XRD and EDS analyses it is confirmed that the nitrided steel is composed of iron nitrides $\left(\gamma^{\prime}-\mathrm{Fe}_{4} \mathrm{~N}, \varepsilon-\mathrm{Fe}_{2-3} \mathrm{~N}\right)$ and the nitrogen in the solid solution which are responsible for the enhancement of corrosion resistance of the steel. Presence of $\varepsilon-\mathrm{Fe}_{2-3} \mathrm{~N}$ predominantly in the nitrided steel attributes to the passivation with much wider region than the bare steel. Both the nitrided steels show better passivation as compared to the bare steel. Nitrogen in the solid solution released increases the alkalinity of the electrolyte in which the steel surface is exposed. Nitrogen in aqueous environment forms ammonium hydroxide which causes the increase in alkalinity of the electrolyte. Nitrogen in aqueous solution forms $\mathrm{NH}_{4}^{+}, \mathrm{NO}^{2-}$ and $\mathrm{NO}^{3-}$ which are thermodynamically stable in the passivation region. Baba et al. [24] reported that the nitrogen reacts with water resulting in the release of ammonium and hydroxide ion thus near the surface of the metal alkalization occurs. It was suggested that the alkalization alone or alkalization with the ions generated are contributing to the passivation in the neutral environment.

From the above discussion it can be concluded that the plasma nitriding is effective in enhancing the electrochemical corrosion resistance significantly at higher temperature.

\section{Conclusions}

Plasma nitriding of $90 \mathrm{CrMoV} 8$ tool steel at a low temperature of $450{ }^{\circ} \mathrm{C}$ shows a wider passivation zone than the bare steel. When compared to the bare steel and the steel nitrided at lower temperature; the corrosion resistance of the steel nitrided at $550{ }^{\circ} \mathrm{C}$ for $10 \mathrm{~h}$ was found to be significantly improved. Nitriding at this higher temperature incorporates higher nitrogen concentration than nitriding at lower concentration. Nitriding generates the super saturation/inclusion of nitrogen, which is beneficial for corrosion resistance by increasing the alkalinity of the electrolyte. The compound layer consisting of $\gamma^{\prime}-\mathrm{Fe}_{4} \mathrm{~N}, \varepsilon-\mathrm{Fe}_{2-3} \mathrm{~N}$ and the nitrogen solid solution are responsible for the enhancement of corrosion. With this enhancement of corrosion resistance the tool life can be prolonged and hence the replacement cost can be saved.

\section{Declaration of Competing Interest}

The authors declare that they have no known competing financial interests or personal relationships that could have appeared to influence the work reported in this paper.

\section{Acknowledgement}

The authors thankfully acknowledge GITAM (Deemed to be University) for kindly giving us the opportunity to carry on this research.

\section{References}

[1] M. Van Stappen, M. Kerkhofs, L.M. Stals, C. Quaeyhaegens, Surf. Coat Tech. 629 (1995) 74-75.

[2] C. Nouveau, M.A. Djouadi, R. Marchal, M. Lambertin, Applications of hard coatings (CrxNy) obtained by PVD methods in wood machining, Méca \& Indus3 (2002) 333. 
[3] M. Bader, H.J. Spies, K. Höck, E. Broszeit, H.J. Schröder, Properties of duplex treated (gas-nitriding and PVD-TiN,-Cr2N) low alloy steel, Surf Coat. Technol. 98 (1998) 891.

[4] A. Chala, L. Chekour, C. Nouveau, C. Saied, M.-S. Aida, M.-A Djouadi, Study of the duplex treatment on $32 \mathrm{CrMoV} 13$ low alloy steel: application in wood machining, Surf. Coat. Technol. 200 (2005) 512.

[5] C. Nouveau, P. Steyer, K. Ram Mohan Rao, D. Lagadrillere, Plasma nitriding of $90 \mathrm{CrMoV} 8$ tool steel for the enhancement of hardness and corrosion resistance, Surf. Coat. Technol. 205 (2011) 4514-4520.

[6] K. Ram Mohan Rao, K. Trinadh, C. Nouveau, Low temperature plasma nitriding of low alloy steel for the enhancement of hardness, Mat. Tod. Proc. 17 (2019) 26-33.

[7] K. Ram Mohan Rao, Kalimi Trinadh, Corinne Nouveau, Elevated temperature plasma nitriding and effects on electrochemical properties of steel, Mat. Tod. Proc. 19 (2019) 867-869.

[8] A. Maniee, F. Mahboubi, R. Soleimani, The study of tribological and corrosion behavior of plasma nitrided 34CrNiMo6 steel under hot and cold wall conditions, Mater. Des. 60 (2014) 599-604.

[9] J. O’Brien, D. Mand Goodman, Plasma (Ion) Nitriding, Metals Handbook, 190 American Society for Metals, Metals Park, OH, 1991, pp. 420-424.

[10] R.M. Muñoz Riofano, L.C. Castteleti, L.C.F. Canale, G.E. Totten, Improved wear resistance of $\mathrm{P} / \mathrm{M}$ tool steel alloy with different vanadium contents after ion nitriding, Wear 265 (2008) 57-64.

[11] E. Arslan, M.C. Igdil, H. Yazici, et al., Mechanical properties and biocompatibility of plasma-nitrided laser-cut 316L cardiovascular stents, J. Mater. Sci. 19 (2008) 2079-2086

[12] G.-H. Zhao, R.E. Aune, N. Espallargas, Tribocorrosion studies of metallic biomaterials: the effect of plasma nitriding and DLC surface modifications, J. Mech. Behav. Biomed. Mater. 63 (2016) 100-114.
[13] H. Forati Rad, A. Amadeh, H. Moradi, Wear assessment of plasma nitrided AISI 214 H11 steel, Mater. Des. 32 (2011) 2635-2643.

[14] D. Cherng Wen, Microstructure and corrosion resistance of the layers formed on the surface of precipitation hardenable plastic mold steel by plasma nitriding, Appl. Surf. Sci. 256 (2009) 797-804.

[15] K. Ram Mohan Rao, Kalimi Trinadh, Corinne Nouveau, Glow discharge plasma nitriding of low alloy steel, Mat. Tod. Proc. 19 (2019) 864-866.

[16] A.S. Loir, D. Pech, P. Steyer, Y. Gachon, C. Héau, J.C. Sanchz-Lopez, Plasma Process. Polym. 4 (2007) 173. 269.

[17] L. Chekour, C. Nouveau, A. Chala, M.A. Djouadi, Surf. Coat. Technol. 200 (2005) 270.

[18] D. Liedtke, U. Huchel, et al., Wärmebehandlung von Eisenwerkstoffen, Nitrieren und Nitrocarburieren, 3rd ed..., Epertverlag, 2005.

[19] H. Michel, T. Czerwiec, M. Gantois, et al., Progress in the analysis of the mechanisms of ion nitriding, Surf. Coat. Technol. 72 (1995) 103-111.

[20] Y. Hirohata, N. Tsuchiya, T. Hino, Effect of mixing of hydrogen into nitrogen plasma, Appl. Surf. Sci. 169-170 (2001) 612-616.

[21] C.A. Figueroa, S. Weber, T. Czerwiec, et al., Oxygen, hydrogen, and deuterium effects on plasma nitriding of metal alloys, Script. Mater. 54 (2006) 13351338.

[22] J.M. Priest, M.J. Baldwina, M.P. Fewell, The action of hydrogen in low-pressure r.f.-plasma nitriding, Surf. Coat. Technol. 145 (2001) 152-163.

[23] Teresa Moskalioviene, Arvaidas Galdikas, Metallurg. Mater. Trans. A 46 (12) (2015) 5588-5595.

[24] H. Baba, T. Kodama, Y. Katada, Role of nitrogen on the corrosion behaviour of austenitic stainless steels, Corros. Sci. 44 (2002) 2393. 